Jurnal Psikologi Teori dan Terapan

2016, Vol.7, No. 1, 26-42, ISSN: 2087-1708

\title{
Pengalaman Interaksi dan Penyesuaian Sosial Waria: Studi Kasus Waria Yang Tinggal di Gang 'X' Surabaya
}

\author{
Renyta Ayu Putri dan Muhammad Syafiq ${ }^{1}$ \\ Program Studi Psikologi Universitas Negeri Surabaya
}

\begin{abstract}
The aim of this study was to understand the experience of social interaction and adjustment among transvestites who live in Gang ' $X$ ' Surabaya. This qualitative study was a case study. The participants were five transvestites selected using purposive and snowball sampling. Data collected using semi-structured interviews and analyzed using thematic analysis. The result shows four themes namely the perception of social acceptance, the experiences of direct interaction, social adjustment of transvestites and the ways the participants use to overcome problem and difficulties in interaction. In general, the transvestites experience both positive and negative reaction from their neighbours. They also participate actively in direct social interaction and give some contribution. However, they still experience some psychological discomfort that requires them to solve. The participants use emotional focused and problem focused coping to solve the problems.
\end{abstract}

Keywords: transvestites, social interactions, social adjustment.

\begin{abstract}
Abstrak: Penelitian ini bertujuan untuk memahami pengalaman interaksi dan penyesuaian sosial waria di Pacarkembang Gang ' $\mathrm{X}$ ' Surabaya. Penelitian ini menggunakan pendekatan kualitatif dengan metode studi kasus. Lima waria dipilih sebagai partisipan menggunakan purposive dan snowball sampling. Data dikumpulkan dengan menggunakan wawancara semi-terstruktur dan observasi semi-partisipan dan dianalisis menggunakan analisis tematik. Hasil penelitian ini menunjukkan empat tema yaitu persepsi penerimaan sosial, pengalaman interaksi secara langsung, penyesuaian sosial waria dan strategi mengatasi masalah dan kesulitan berinteraksi. Secara umum, waria mendapatkan reaksi secara positif maupun negatif dari warga sekitar. Mereka juga berpartisipasi aktif dalam interaksi sosial secara langsung dan memberikan kontribusi dalam kegiatan tertentu di kampunya. Namun, mereka masih mengalami beberapa permasalahan yang mengharuskan mereka untuk mengatasinya. Para partisipan menggunakan strategi berfokus pada emosi dan berfokus pada problem dalam rangka mengatasi kesulitan dari lingkungannya.
\end{abstract}

Kata Kunci: waria, interaksi sosial, penyesuaian sosial.

Secara umum manusia terdiri atas laki-laki dan perempuan. Identitas laki-laki atau perempuan ditentukan oleh jenis kelamin dan gender. Gender merujuk pada sesuatu yang berhubungan dengan jenis kelamin, seperti perilaku, peran, karakteristik kepribadian, kecenderungan, dan atribut-atribut lain yang dapat mengidentifikasikan seseorang menjadi seorang laki-laki atau perempuan (Baron \& Byrne, 2004). Sebagian besar individu memiliki identitas gender sesuai dengan jenis kelaminnya, laki-laki dengan gender maskulin dan perempuan dengan gender

Korespondensi tentang artikel ini dapat dialamatkan kepada Renita A. Putri melalui email: renyta.psiko@yahoo.co.id; atau M. Syafiq melalui email: muhammadsyafiq@unesa.ac.id. 
feminin. Beberapa orang memiliki identitas gender yang berbeda dari jenis kelamin, menjadikan mereka kaum minoritas (Baron \& Byrne, 2004). Inilah yang kemudian menimbulkan sebuah perbedaan atau bahkan masyarakat mengenalnya sebagai abnormalitas orientasi seksual dan identitas gender.

Orientasi seksual dan identitas gender yang berbeda dengan mayoritas ini lebih dikenal dengan singkatan LGBTI (Lesbian, Gay, Biseksual, Transgender, dan Interseksual). Di antara keempat jenis penyimpangan orientasi seksual tersebut, transgender menjadi satu-satunya yang masih termasuk dalam jenis gangguan jiwa. Transgender masih digolongkan sebagai gangguan jiwa dalam DSM V (Diagnostic and Statistical Manual of Mental Disorders, Fifth Edition) yang diakui sebagai pedoman diagnosis gangguan jiwa secara internasional. Transgender dalam DSM V termasuk dalam gangguan yang disebut Gender Dysphoria, di mana istilah tersebut mengacu pada ketidakpuasan seseorang secara afek maupun kognitif terhadap jenis kelaminnya (APA, 2013).

Di antara pria transgender dan wanita transgender terdapat perbandingan yang sangat kentara, meskipun belum ada data statistik yang mampu menunjukkan jumlah pasti dari kedua transgender tersebut. Suryadjaja (2014) memperkirakan transgender ada pada masing-masing jenis kelamin, 1 dari 30.000 pria dan 1 dari 100.000 wanita.

Direktorat Rehabilitasi Sosial Tuna Sosial, Kementerian Sosial Republik Indonesia (2012) pada tahun 2010 mengumpulkan data jumlah pria transgender di Indonesia yang mencapai 31.179 jiwa. Jawa Timur adalah provinsi yang menduduki peringkat pertama di Indonesia dengan jumlah pria transgender terbanyak yaitu 4.170 jiwa.

Seorang transgender tidak merasa nyaman dengan tubuhnya dan secara psikologis merasa bahwa gendernya berbeda dari jenis kelaminnya (Taylor dkk., 2009). Transgender seringkali merasa bahwa dirinya terjebak di tubuh yang berlainan jenis kelamin. Seorang pria transgender berpenampilan, berekspresi, dan ingin diperlakukan sebagai wanita. Jumlah pria transgender yang begitu banyak kemudian akan memunculkan berbagai persoalan, terlebih seorang pria yang berpenampilan layaknya wanita akan lebih menarik perhatian daripada seorang wanita yang berpenampilan seperti lakilaki.

Pria transgender dikenal dengan sebutan waria (singkatan dari wanita pria), atau juga dikenal sebagai wadam (singkatan hawa adam), oleh orang awam disebut banci (Koeswinarno, 2004). Peneliti menggunakan istilah waria dalam penelitian ini menggantikan istilah wadam, banci, pria transgender, atau gender dysphoria, karena waria merupakan representasi dari bahasa Indonesia dan lebih dikenali dan dipahami oleh masyarakat umum.

Theodorson \& Theodorson (dalam Danandjaja, 2003) menyatakan bahwa kelompok minoritas sering mendapatkan perilaku diskriminatif dan prasangka dari sebagian besar masyarakat. Penelitian di Asia-Pasifik mengindikasi bahwa stigma dan prasangka merupakan masalah besar bagi transgender (Winter, 2012). Waria merupakan salah satu dari sekian banyak kelompok minoritas. Hampir di setiap negara, kelompok ini tidak mendapatkan hak-hak yang semestinya didapat orang pada umumnya dan didiskriminasi oleh lingkungan dan masyarakat. Sikap sosial dan budaya dalam menghadapi ragam orientasi seksual dan identitas gender bertolak belakang jauh dengan apa yang diharapkan oleh kaum minoritas tersebut. Perilaku diskriminatif tersebut tidak jarang diterima karena waria adalah kelompok minoritas dari masyarakat dunia.

Sebagai makhluk individu maupun makhluk sosial, waria berusaha untuk mendapat bagian dalam berbagai ruang 
sosial (Koeswinarno, 2004). Sedangkan pola diskriminasi yang biasa dilakukan masyarakat terhadap waria menyebabkan waria merasa diasingkan dan tidak diterima secara sosial oleh lingkungannya. Oleh karena itu, waria dalam mewujudkan kehidupan sosialnya dengan masyarakat umum akan membutuhkan usaha yang cukup besar.

Hinshaw (2005) menyatakan bahwa orang yang terstigmatisasi dan terdiskriminasi oleh lingkungannya memiliki status sosial yang rendah. Oleh karena itu, apabila waria masih didiskriminasi, mereka akan kesulitan dalam melakukan interaksi dan penyesuaian sosial.

Perasaan terasingkan di lingkungan waria ini juga membuat mereka pergi dari rumah atau lingkungannya tinggal. Lebih banyak waria kemudian memilih untuk tinggal atau berkumpul bersama sesama waria (Koeswinarno, 2004). Di tempat baru, waria juga perlu mewujudkan kebutuhan-kebutuhan sosialnya. Bentuk umum dari proses sosial adalah interaksi sosial dan penyesuaian diri secara sosial (social adjustment) (Soekanto, 2003).

Interaksi yang baik dengan orang lain juga dapat menjadi salah satu strategi untuk mengurangi stigma dan diskriminasi. Interaksi yang dimaksudkan tidak hanya dilakukan sekali, namun harus berkali-kali (Corrigan, 2004). Interaksi yang dilakukan secara berulang dengan orang baru akan membuat waria merasa perlu untuk menyesuaikan dirinya secara sosial. Waria yang mampu berhasil dalam menyesuaikan diri dan berinteraksi secara sosial, maka akan mempermudah dirinya untuk diterima oleh lingkungannya. Penerimaan tersebut kemudian memenuhi kebutuhan sosial waria.

Tidak semua waria kemudian melakukan usaha untuk berinteraksi dengan masyarakat sekitar dan menyesuaikan dirinya secara sosial. Penelitian yang dilakukan oleh Ningsih \& Syafiq (2014) menemukan bahwa waria, dalam usaha atau strateginya untuk bertahan secara sosial adalah dengan dua cara, yaitu bergabung dengan kelompok waria serta mengabaikan orang lain. Kedua cara tersebut dirasa waria lebih mudah untuk dilakukan, karena melakukan interaksi positif dengan orang lain akan lebih sulit bagi waria.

Tantangan dan pengalaman yang dihadapi oleh waria dalam usahanya untuk menyesuaikan diri dengan lingkungan sosial serta berinteraksi dengan orang lain tersebut kemudian akan menarik apabila diteliti lebih lanjut secara ilmiah.

Strategi-strategi waria bukan tidak mungkin berhasil diterapkan untuk mendapatkan kesetaraan sosial dari masyarakat sekitar. Beberapa bukti bahwa waria mampu berhasil menyesuaikan dirinya dan melakukan interaksi sosial yaitu terdapat kontes kecantikan di Jakarta yang dimenangkan oleh waria dan Indonesia memiliki bunda Dorce, seorang presenter transeksual (transgender yang melakukan operasi organ seksual) (Huang, 2012).

Di daerah Kampung Dayak, Kabupaten Banyumas, masyarakat sudah menerima waria dengan positif. Di daerah Badran, Yogyakarta, waria pendatang bahkan sangat menyatu dengan masyarakat sekitar. Mereka melakukan aktivitas bersama dengan masyarakat setempat dan berpartisipasi dalam berbagai kegiatan ibuibu, seperti arisan dan PKK (Nadia, 2005). Di Bone, Sulawesi Selatan, waria bahkan ditempatkan perannya dalam ritual keagamaan (Haq, 2012). Waria disebut sebagai Bissu, yang pada jaman dahulu adalah penasehat kerajaan, yang pada saat ini bertugas menjaga pusaka. Bissu adalah laki-laki yang mengenakan pakaian perempuan, dan identik memiliki kebiasaan atau perilaku seperti perempuan.

Surabaya menjadi salah satu kota terpilih bagi para waria untuk tinggal dan mencari rejeki. Beberapa wilayah ditinggali oleh waria di Surabaya, namun jarang yang tinggal secara berkelompok. 
Salah satu wilayah Surabaya yang menjadi tempat tinggal waria secara berkelompok adalah di Pacarkembang Gang ' $X$ '. Di gang ini terdapat dua rumah kos khusus untuk waria. Di dalamnya tinggal dua puluh waria pendatang. Kedua puluh waria tersebut memiliki profesi sebagai pekerja seks komersial (PSK) di tempat lain di Surabaya. Beberapa diketahui terjangkit virus HIV. Tetapi dengan status yang demikian jauh dari norma masyarakat, waria dapat bertahan hidup di Gang ' $X$ '.

Di Gang ' $X$ ' ini waria juga dapat berhubungan sosial dengan para tetangga atau warga lain. Kedua rumah kos yang ditinggali oleh sekelompok waria ini telah diijinkan oleh ketua RT di Gang ' $\mathrm{X}$ '. Pengakuan ketua RT mengatakan bahwa belum pernah ada masalah antara warga dengan waria di kampung ini selama sepuluh tahun lebih rumah kos tersebut ada.

Waria dapat bertahan di Gang ' $X$ ' selama bertahun-tahun tentu tidak lepas dari usahanya untuk menyesuaikan diri dan menjalin interaksi sosial sehingga tidak ditolak di tempat tersebut. Berdasarkan latar belakang di atas, dibahas dua poin penting sebagai fokus kajian yaitu pengalaman interaksi sosial serta penyesuaian sosial yang diterapkan waria di Gang ' $\mathrm{X}$ ' agar mereka dapat diterima dengan baik oleh lingkungannya.

\section{Metode}

Penelitian mengenai interaksi sosial dan penyesuaian sosial ini menggunakan metode kualitatif dengan pendekatan studi kasus yang bertujuan untuk mengetahui secara mendalam pengalaman personal individu, namun masih tetap membutuhkan data sekunder dari orang lain selain partisipan utama. Jenis studi kasus dalam penelitian ini adalah studi kasus instrumental yang memiliki tujuan untuk memberikan pemahaman atau menjelaskan kembali suatu proses generalisasi, dalam hal ini usaha waria dalam menyesuaikan diri secara sosial dan berinteraksi yang kemudian mengungkapkan sisi berbeda dari pola diskriminasi masyarakat.

\section{Partisipan}

Penelitian ini dilakukan di salah satu wilayah di Surabaya, Pacarkembang Gang ' $X$ '. Wilayah tersebut memiliki dua rumah kos yang ditinggali oleh sebanyak dua puluh waria pekerja seks komersial.

Pengambilan partisipan dalam penelitian ini menggunakan teknik purposive sampling dengan karakteristik partisipan adalah seorang waria yang sedang tinggal di Gang ' $\mathrm{X}$ ' dan bersedia menjadi partisipan dalam penelitian ini. Peneliti juga menggunakan teknik snowball sampling, dimana peneliti mendapatkan rekomendasi partisipan dari partisipan sebelumnya. Kemudian ditemukan satu waria bernama Sonya yang merupakan pemilik kos waria di Gang ' $X$ ' sebagai partisipan pertama. Sonya merekomendasikan empat waria lainnya untuk dijadikan partisipan penelitian. Penelitian ini menjadikan lima waria sebagai partisipan dari total dua puluh waria yang tinggal di Gang ' $X$ '.

Tabel 1. Identitas Partisipan Penelitian

\begin{tabular}{ccc}
\hline Nama & Usia & Lama tinggal \\
\hline Sonya & 53 tahun & 53 tahun \\
Fitri & 26 tahun & 3 tahun \\
Icha & 32 tahun & 8 tahun \\
Suci & 24 tahun & 4 tahun \\
Anas & 37 tahun & $<1$ tahun (8 bulan) \\
\hline
\end{tabular}

\section{Teknik pengumpulan data}

Teknik pengumpulan data dalam penelitian ini menggunakan wawancara semi terstruktur dan observasi semi partisipan. Instrumen wawancara yang digunakan adalah pedoman wawancara dan alat perekam. Sedangkan instrumen observasi yaitu catatan lapangan.

Wawancara dilakukan secara fleksibel sehingga tidak mengganggu waktu partisipan. Keseluruhan proses wawancara 
partisipan dilakukan di ruang tamu rumah Sonya dan saat sore hari. Wawancara tidak hanya dilakukan kepada partisipan utama yaitu waria. Serangkaian penelitian ini juga membutuhkan data wawancara dari significant other. Proses wawancara terhadap significant other dilakukan di berbagai tempat yang masih merupakan wilayah dari Gang ' $X$ ', seperti rumah dari significant other, warung, dan toko. Wawancara direkam dengan menggunakan smartphone.

Observasi dilakukan pada setiap kesempatan peneliti berada dalam lokasi penelitian atau berada satu tempat dengan partisipan penelitian selama proses penelitian berlangsung. Partisipan memahami bahwa peneliti sedang melakukan pengamatan terhadap diri mereka, namun peneliti tidak terlibat dalam kegiatan mereka secara langsung.

\section{Teknik Analisis Data}

Teknik analisis data dalam penelitian ini menggunakan analisis tematik. Teknik analisis tematik memungkinkan peneliti untuk melibatkan teori dalam menganalisis data yang lebih mendalam. Braun \& Clarke (2006), mengungkapkan enam langkah dalam melakukan analisis tematik yaitu: (1) membaca ulang data, mencatat ide-ide penting, dan memahami data; (2) mentraskrip data dengan mengelompokkan data atau ide penting dalam kode-kode tertentu (coding); (3) mengumpulkan kodekode yang relevan dalam suatu tema yang lebih besar; (4) me-re-check tema apakah berhubungan dengan kode dan sisa data; (5) mendefinisikan tema dan memberi nama tema; dan (6) menganalisis tema dengan menghubungkannya pada literatur.

Lambang titik-titik dalam kurung persegi, '[...]', digunakan dalam ekstrak data yang dikutip untuk menunjukkan bahwa ada bagian data yang dihapus karena melebar dari topik yang sedang dibicarakan oleh partisipan. Selain itu, tanda kurung '( $)$ ' digunakan untuk mengklarifikasi makna serta memberikan penjelasan tertentu dalam ekstrak data.

Keabsahan data penelitian ini diupayakan oleh peneliti dengan melakukan wawancara terhadap beberapa significant other yang dekat dan yang mengerti keseharian partisipan penelitian. Ada enam warga Gang ' $X$ ' yang berhasil direkrut sebagai sebagai significant other.

Tabel 2 Identitas significant other

\begin{tabular}{cccc}
\hline Kode & Status & $\begin{array}{c}\text { Kependuduk } \\
\text { an }\end{array}$ & $\begin{array}{c}\text { Lama } \\
\text { tinggal }\end{array}$ \\
\hline SO 1 & $\begin{array}{c}\text { Penjual makanan } \\
\text { Penjual nasi } \\
\text { penyet }\end{array}$ & $\begin{array}{c}\text { Penduduk } \\
\text { asli }\end{array}$ & 53 tahun \\
SO 2 & $\begin{array}{c}\text { Pendatang } \\
\text { Penduduk }\end{array}$ & 22 tahun \\
SO 3 & Bu RT Gang ' $X$ ' & $\begin{array}{c}\text { asli } \\
\text { Penduduk } \\
\text { asli }\end{array}$ & 65 tahun \\
SO 4 & Pak RT Gang ' $X$ ' & \begin{tabular}{c} 
Pahun \\
\hline
\end{tabular} \\
\hline
\end{tabular}

\section{Hasil}

Penelitian ini bertujuan untuk mengungkapkan pengalaman interaksi dan penyesuaian sosial waria di Gang ' $\mathrm{X}$ '. Kedua tujuan tersebut berhasil dijelaskan oleh 4 tema besar, yaitu: (1) persepsi terhadap penerimaan warga; (2) pengalaman interaksi secara langsung; (3) penyesuaian sosial waria; dan (4) strategi mengatasi masalah dan kesulitan berinteraksi.

\section{Persepsi terhadap Penerimaan Warga}

Dalam sudut pandang waria serta didukung beberapa pernyataan dari tetangga di Gang ' $\mathrm{X}$ ', maka ditemukan bahwa sebagian warga menerima keberadaan waria, sebagian menolak, dan sebagian besar tidak peduli dan bewarga rsikap tak acuh terhadap waria.

\section{Warga menerima}

Penerimaan warga menjadi salah satu bagian penting bagi waria untuk bertahan di lingkungannya. Semakin waria merasa nyaman, semakin dirinya merasa diterima. 
"Alhamdulillah kayaknya sih sudah. Sudah [...] alhamdulillah mereka juga sepertinya bisa menerima." (Anas)

Persepsi waria bahwa warga sudah menerima didukung oleh ungkapan oleh tetangga.

"Iya. Sudah lah menerima lah mbak kalau saya. Saya itu dari kecil di sini. Sudah besar ya yang mbikinin mereka makanan tiap hari kalau gak menerima saya tutup warung. (tertawa)" (SO 1)

Penerimaan warga tidak semata-mata terjadi begitu saja. Faktor yang dianggap mempengaruhinya, salah satunya adalah karena terbiasa dengan waria yang tinggal di Gang 'X'.

"[...] soalnya kos-kosan waria di sini tuh udah lebih dari dua puluh tahun yang lalu. Pasti banyak udah welcome semua, udah tahu semua." (Fitri)

Pendapat di atas disetujui oleh para tetangga. Perasaan terbiasa akhirnya menjadikan tetangga tidak lagi merasa takut, terkejut, ataupun rasa lain yang menunjukkan penolakan terhadap waria.

"Iya. Dulu, sekarang sih nggak. Sudah wes biasa. Masalahnya sudah lama." (SO 3)

Penerimaan warga juga dipengaruhi oleh peran Sonya yang merupakan tuan rumah kos yang juga merupakan warga asli Gang ' $\mathrm{X}$ '.

"Orang kampung sini juga ada yang segan sama saya mungkin karena saya dibesarkan di sini ya [...]" (Sonya)

\section{Penolakan warga}

Tidak semua waria merasa bahwa warga menerima mereka dengan sepenuhnya. Penerimaan yang dirasakan oleh waria hanya terbatas oleh orang-orang tertentu di sekitar rumah kos.
“[...] Gak mungkin lah satu kampung sini nerima kita semua di sini paling Cuma sekitar gang tiga aja sini tetangga sini-sini [...]"(Icha)

Penolakan terhadap waria ini juga jelas ditunjukkan oleh warga terhadap waria dengan pernyataan berikut.

"harapan saya ke depan mungkin ke depannya mungkin si banci itu, mungkin ya saya peringatkan pelan-pelan supaya tidak kos di sini kedepannya ya." (SO 4)

Tidak hanya sekedar perkataan, tetapi penolakan terhadap waria juga ditunjukkan oleh tingkah laku dari tetangga.

"Fitri dan peneliti berjalan menuju rumah pak RT yang berada di dalam gang kecil berjarak kurang lebih sepuluh rumah dari kos-kosan waria. Pintu rumah Pak RT terbuka tetapi tidak terlihat orang di ruangan depan. Fitri kemudian memanggil pak RT dan mengucapkan salam berkali-kali hingga dibalik korden terlihat seorang dewasa tetapi tidak keluar dan tidak lama seorang anak kecil keluar dan mengatakan bahwa ayahnya tidak ada di rumah. Tidak lama kemudian seorang pria keluar dari pintu lain [...]" (CL 2)

\section{Sikap apatis warga}

Sebagian besar data menunjukkan bahwa warga lebih cenderung memiliki sikap tidak peduli terhadap keberadaan waria.

\begin{abstract}
"Cuek. Yaitu tadi suangat cuek. Kalau sampean tau sangat cuek sekali orangorang ya gak mau gak ngurusin gitu lho mbak. Kamu mau bertengkar mau apa itu urusan kamu. Gitu." (Anas)
\end{abstract}

Data di atas didukung pula oleh pernyataan beberapa tetangga yang mengaku apatis kepada mereka.

"Ah yo biarin. Gak mau tahu. Gak bikin masalah. orang-orang kalau ngelarang gak mau ikut campur." (SO 3) 


\section{Pengalaman lnteraksi langsung}

Sebagai bagian dari warga Gang ' $X$ ' pula, maka merupakan suatu kebutuhan untuk berinteraksi dengan lingkungan tempat tinggalnya. Berikut adalah berbagai pengalaman partisipan dalam berinteraksi dengan orang sekitar.

\section{Komunikasi dengan tetangga}

Intensitas waria dalam berinteraksi dengan warga Gang ' $X$ ' tentu saja juga ditunjukkan dengan adanya komunikasi secara pribadi dengan tetangga sekitar. Pengalaman komunikasi positif paling kecil yang dilakukan adalah dengan saling menyapa satu sama lain.

"Emm seperti biasa saya ya senyum kalau misalkan disapa saya senyum walaupun gak disapa saya sapa duluan." (Anas)

Seringkali waria juga berbincang-bincang menceritakan pengalamannya dengan beberapa tetangga yang memang dikenal dekat.

"[...] Cuma ngomong udah biasa aja. Kadang misalnya ngobrol sama banci cucok ya semalam yo, oleh, oleh lanang piro. Gitu. Cucok ya semalam piro semalam dapat duit banyak ya. [...]" (Icha)

Tak jarang kesempatan untuk berbincangbincang ini digunakan juga sebagai senda gurau bahkan mereka sering kongko bersama para tetangga.

“[...] kalau aku kan suka bercanda bercanda ngobrolin ini masalah ini ini ini." (Icha)

"Ini nih di sebelah situ. Nah itu kan karena saya kan ya sering nongkrong situ juga ngobrol-ngobrol apa ini saya juga sering belanja, sering beli-beli minuman di situ ya nongkrong juga.[...]." (Anas)

Keakraban waria dengan para tetangga juga didukung oleh hobby yang sama yang dimiliki oleh keduanya. Salah satu kegemaran yang dimilikiAnas dan beberapa waria lain adalah melihat serial drama televisi.

"Disukai naah ini di sini apa tuh kita di sini tuh bertiga. Linda, Meme, sama aku. Jadi mungkin gara-gara ikutan film ya film Jodha Akbar itu (ketawa) ya jadi kita sukanya ya ini warga-warga yang ibu-ibu warung gitu belanja saya pake acara-acara salam [...]" (Anas)

Para partisipan menyadari bahwa mereka membutuhkan berinteraksi dengan tetangga sekitar, karena bagaimanapun waria tetaplah bagian dari masyarakat yang saling membutuhkan.

"Ya pasti butuh lah. Orang itu gak mungkin hidup individual kan. Ya pasti saling membutuhkan kan.” (Fitri)

\section{Partisipasi Kegiatan Bersama}

Sebagai perwujudan seorang warga, berbagai kegiatan kampung dilakukan oleh para waria. Salah satu yang dilakukan adalah turut memeriahkan pesta perayaan Hari Ulang Tahun Kemerdekaan Republik Indonesia.

"Iya acara-acara tujuh belasan kan waria nyumbang ada acara panggung gitu. Kalau ada tujuh belasan gitu kan kita ada yang pinter nyanyi, nari gitu tampil." (Fitri)

Saat perayaan Hari Ulang Tahun (HUT) Kemerdekaan RI, waria pun dipercayai warga Gang ' $\mathrm{X}$ ' untuk menjadi juri dari beberapa lomba.
"Apalagi kalau ada lomba joget kadang kita disuruh jadi juri juga. Saya suruh njuri, kadang-kadang sih kalau ada agustusan juga disuruh njuri, kalau lomba joget suruh njuri, lomba fashion show suruh njuri [...]" (Sonya)

Anas bahkan memberikan ilmunya menari kepada anak-anak sekitar Gang ' $\mathrm{X}$ ' untuk 
kemudian ditampilkan saat perayaan HUT Kemerdekaan RI.

"Kalau tujuh belasan ada. Cuman ya paling ya bikin anak-anak menari gitu kan mengajarnya nari-nari juga[...]" (Anas)

Tidak hanya saat perayaan HUT Kemerdekaan RI, beberapa waria juga turut serta arisan bersama ibu-ibu setempat.

"[...]kalau ada ibu-ibu arisan di sini ya kita diundang sama orang kampung ini juga ya ikut [...]" (Sonya)

Partisipasi waria tidak berhenti sampai di situ. Ketika warga sedang mengadakan pesta, beberapa waria yang dikenal akan diundang. "Ya ada kalau orang hajatan pasti
diundang kita." (Fitri)

Tidak hanya datang sebagai tamu, tak jarang waria diminta warga untuk mengisi hiburan di pesta tersebut.

“[...]Kalau mereka ada acara apa-apa. Ada acara misalnya dia punya hajatan pengantin gitu mereka ngomong ke saya, ada ini bisa nari gak? Bisa pentas ya? Berapa? Ya kasih berapa aja, semampunya aja. Semampunya ibu aja" (Sonya)

\section{Memberi Sumbangan}

Waria sebagai warga Gang ' $X$ ' seringkali memberikan sumbangan berupa materi. Salah satu yang rutin dilakukan adalah memberi dana sumbangan saat kerja bakti.

"[...] Kalau ada kerja bakti gitu kita urunan, kita walaupun gak ikut kerja bakti gitu kita, kita apa tuh, kolektif gitu ya, kita kasihkan orang untuk beli kue, beli rokok, gitu [...]"(Sonya)

Bahkan waria, selayaknya warga Gang ' $X$ ' yang patuh, mereka secara rutin membayar iuran kas.
“[...] biasa seperti warga warga kita sendiri karena dia disiplin tiap bulan bayar iuran."(SO 4)

Di luar sumbangan rutin dan iuran rutin, waria juga menjadi donatur hadiah lomba di perayaan HUT Kemerdekaan RI.

“[...]dan lagi anu dikasih donatur dikasih hadiah anak-anak yang lomba yang menang." (SO 4)

\section{Masalah interaksi dan penyesuaian diri}

Status Sosial waria yang masih sulit diterima, membuat mereka juga mengalami berbagai masalah dan kesulitan dalam kehidupan sosialnya. Beberapa orang masih memperlakukan waria dengan buruk, utamanya orang-orang yang mabuk.
"[...]kadang-kadang kalau ada teman- teman, apa tuh, kalau ada orang mabuk- mabuk gitu lho kalau malam-malam itu kadang-kadang tuh teriak-teriak, kamar- kamar tuh didodok-dodok (diketuk- ketuk). Kalau didodok-dodok mereka itu maksudnya minta uang, kadang-kadang minta dilayani hubungan seks gitu [...]" (Sonya)

Selain diperlakukan buruk oleh orang mabuk, waria juga pernah diusir oleh ketua RT setempat karena melakukan keributan.
"Pengalaman buruk ya kadang-kadang itu kalau ada waria yang ribut aja tiba- tiba sama RT nya diusir" (Sonya)

Waria juga pernah ditegur secara langsung oleh tetangga yang merasa terganggu dengan tingkah atau saat mendengar keributan dari para waria.
"Tetangga sebelah itu, kadang-kadang tuh 'heh ojo rame ae po'o! Banci rame ae' ('jangan rame saja! Banci ramai terus') terus tersinggung gitu ya, kami marah.”(Sonya)

Dengan penampilan yang berbeda dari warga lainnya, mereka seringkali digoda oleh tetangga sekitar. 
"Ya paling nggak suka sama tetangga kalau tetangga tuh resek kayak gitu, kalau godain berlebihan gitu gak suka" (Fitri)

Saat ini waria jarang mendapatkan hinaan dari orang-orang dewasa, namun hampir setiap hari waria pasti menerima hinaan dari anak-anak sekitar.

"Kalau orang dewasanya sih alhamdulillah gak ada. Tapi kalau anak kecil ya tiap hari (tertawa). Ada ada aja.'(Anas)

Tidak semua warga menerima keberadaan waria, sehingga dijauhi atau dihindari oleh orang tertentu menjadi salah satu masalah interaksi bagi waria.

"Kesulitannya sih mungkin ya kayak orang-orang yang mahasiswa kayaknya mahasiswa laki-laki ya mbak mahasiswa tuh kan belum tentu bisa menerima keadaan kita yang kayak gini” (Anas)

\section{Pengalaman psikologis dalam interaksi}

Pengalaman emosional pasti terjadi di setiap melakukan aktivitas apapun, terutama ketika berhubungan secara sosial dengan orang lain. Partisipan juga merasakan perasaan yang berbeda dengan orang lain ketika melakukan interaksi bersama orang yang berbeda darinya. Salah satunya adalah perasaan takut akan penolakan orang.

"Dari awal itu cuman dua orang aja yang ngekos saya takut ya Cuma dua aja takutnya orang-orang kampung ini gak mau nerima[...]" (Sonya)

"[...] ya ketir-ketir juga tiap malem. Kan mereka kan tiap malemnya mejeng, pulang bawa tamu kan rame-rame kadang-kadang. Ya gitu orang kampung marah-marah akhirnya yang punya rumah itu yang kena, saya disalahin. (Sonya)

Waria memiliki identitas yang berbeda dengan warga pada umumnya. Statusnya tersebut menjadikan mereka merasa malu melakukan interaksi kepada orang sekitar.

"Ya malu ya namanya kita kan beda kan kita bukan perempuan bukan laki-laki kan kayak di tengah-tengah gitu lho. Jadi ya malu sama yang lain orang-orang itu" (Suci)

Salah satu perasaan positif yang terungkap saat waria berinteraksi dengan tetangga adalah perasaan dimengerti oleh warga. Perasaan ini dialami oleh Icha.
"[...]kalau masalah apa sih orang-orang sini tuh tahu sifat aku gitu lho. Udah tahu sifat aku. Suka ngomel-ngomel katanya kalau misalkan beli itu maunya cepat. [...]"'(Icha)

\section{Penyesuaian Sosial Waria}

Waria Gang ' $X$ ' yang hampir keseluruhannya adalah seorang pendatang membutuhkan dirinya untuk menyesuaikan dirinya secara sosial. Mereka mengubah diri untuk dapat sesuai dengan lingkungan, serta peran Sonya dapat mengubah lingkungan dengan menggunakan otorisasi secara tidak langsung.

\section{Menyesuaikan diri dengan Lingkungan}

Berbagai sikap mereka munculkan agar warga-warga Gang ' $\mathrm{X}$ ' mampu menerima keberadaan mereka di sekitarnya. Salah satunya adalah dengan berusaha aktif sebagai warga dalam kegiatan.

"Secara gak langsung waria di sini itu juga ngasih imbalan berupa acara atau apa gitu" (Sonya)

“[...] tiap minggu tuh di sini kan diadakan kerja bakti. Sementara kalau malam minggu anak-anak tuh pada kelelahan pulang, apa pulangnya kan pagi. Karena waktu yang paling lama kan paling ramai jadi anak-anak pada kecapekan semua gitu. Bagaimana caranya aku bisa baik sama orang-orang di sini ini lho. [...] aku mintain anakanak sepuluh ribuan satu orang, mana 
sini uang sepuluh ribu. Buat apa ini? Nggak ini lho aku mau beliin pak RT ee beliin rokok beliin makanan sama orang kerja bakti [...]" (Icha)

Mendekatkan diri dan kongko dengan orang lain merupakan cara lain para partisipan yang benar-benar ingin menjalin hubungan sosial yang baik dengan tetangga. mereka berusaha untuk membuka diri di hadapan tetangga.

"Ehm mungkin ya itu tadi salah satunya dengan salah satunya ikut ya nongkrong di warung sering belanja, karena dengan sering itu ya sering belanja itu ya jadi deket kan bicara juga ngobrol-ngobrol." (Anas)

Mereka juga berusaha untuk berbuat baik agar dapat diterima oleh lingkungan sekitar.

"[...] karena saya baik sama warga situ juga akhirnya saya diterima juga sih." (Anas)

Selain berbuat baik, sebisa mungkin mereka dapat berguna sebagai warga. Salah satunya dari pernyataan Icha berikut.

“[...] ya setidaknya ada poin lah buat pak RT oh ternyata anak ini meskipun sifatnya seperti ini meskipun dia sesosok waria, dijelekin atau dikatain sama orang sama masyarakat tapi setidaknya bisa berguna buat orang kampung sini. Kayak gitu aku." (Icha)

Waria lain yang tinggal lebih lama dan lebih dulu mengenal tetangga juga saling membantu waria baru untuk menyesuaikan diri.

"Setelah teman-teman ayo nongkrong situ di warung. Jadi akhirnya kan apa namanya e kenal sama anak-anak sini jadi kenal si A si B. Jadi mereka oh baru ya, iya." (Anas)

\section{Mengatasi kesulitan interaksi}

Berbagai kesulitan dan permasalahan yang dialami waria dalam berikehidupan sosial, menuntut mereka untuk menemukan cara menghadapi atau menyelesaikan permasalahan tersebut.

\section{Mengatur emosi}

Berbagai hinaan dan perlakuan buruk yang dialami oleh para partisipan membuat berbagai emosi muncul dalam benak mereka. Partisipan kemudian tidak jarang menahan emosi negatif muncul, dengan bersabar, pasrah, serta menerima perlakuan buruk orang lain.

"Yaa sabar aja lah, namanya juga berbeda ya, dihina gitu ya cuma bisa sabar. Tuhan kan Maha Adil. Yaa biar Tuhan aja yang balas" (Suci)

"Ya saya diam. Karena saya ya memang saya ini ya banci saya harus terima gitu mbak.’(Anas)

"Warga sendiri ya gak papa, tapi ya ada yang usil eh jadi laki-laki ganteng ngapain dadi wedok (kenapa jadi perempuan). Ya pokoknya diem aja." (Sonya)

Para partisipan juga cenderung mengabaikan perlakuan negatif agar mereka lebih merasa nyaman dengan lingkungan sosialnya.

"Ya cuek aja, ngapain dipikirin. Toh aku nggak minta makan mereka." (Fitri)

"Ya meskipun kalau ada yang resek (mengganggu) ya biar biarin aja. Ya biarin aja ngapain." (Icha)

\section{Bertindak menghadapi masalah}

Beberapa kali partisipan juga marah ketika dihina berlebihan, seperti yang diungkapkan oleh Icha.

"Ya aku ngomong. Kenapa kamu ngejek aku gitu? Bukan urusan kamu, kok ngurusin. Terus apa masalahnya kamu. Makan ya gak minta kamu, kamu siapa aku siapa itu bukun urusan kamu bukan." (Icha) 
Beberapa masalah lainnya diselesaikan oleh waria dengan melakukan tindakan penyelesaian, seperti dengan meminta maaf.

"kadang-kadang saya minta maaf akhirnya gak jadi (bertengkar), ya mereka ngerti. Tapi kalau mereka sendiri gak bisa ya saya (yang minta maaf)." (Sonya)

\section{Pembahasan}

Seperti kelompok minoritas lainnya, waria sering mendapatkan perilaku diskriminatif dan prasangka (Theodorson \& Theodorson, dalam Danandjaja, 2003). Pengalaman-pengalaman waria terkait stigma dan prasangka terhadap mereka ini kemudian berdampak kepada kehidupan sosial waria.

Berbagai pengalaman interaksi dan penyesuaian sosial partisipan membuat mereka menyimpulkan sudut pandang tertentu mengenai penerimaan warga. Secara psikologis, penerimaan sosial merupakan kebutuhan dasar bagi makhluk sosial. Seseorang akan dapat memenuhi kebutuhan untuk diperhatikan dan diakui keberadaannya, ketika dirinya diterima oleh lingkungan sekitarnya.

Keseluruhan partisipan mengatakan bahwa mereka merasa warga telah menerima keberadaannya. Salah satu warga yang juga menyatakan diri menerima para waria adalah penjual makanan khusus waria, yang memiliki kesempatan besar untuk menjalin interaksi dengan para waria.

Adapun partisipan mengira warga menerima karena telah terbiasa dengan keberadaan waria yang telah dua puluh tahun lebih di Gang ' $X$ '. Masyarakat tidak bisa menolak waria sebagai sebuah realitas, karena waria ada dalam sejarah kehidupan manusia, sehingga mayarakat dituntut mengakuinya. Waria cukup lama bersemayam, sehingga kemungkinan besar membuat warga 'mau tidak mau' menerima keberadaan mereka.
Sonya adalah pemilik rumah kos waria. Statusnya sebagai warga asli dan usianya yang cukup tua membuatnya sebagai orang yang dihormati di Gang ' $X$ '. Warga yang menaruh hormat terhadap dirinya membuat para waria dapat bertahan di Gang ' $X$ '. Penduduk yang mayoritas pendatang, juga merasa tidak berhak mengusir waria yang telah ada terlebih dahulu.

Penerimaan yang dirasakan partisipan terbatas pada lingkup 3-4 rumah di sekitar. Ahmadi (2007) mengatakan bahwa stereotip dan prasangka terhadap sesuatu dapat dilenyapkan dengan melakukan interaksi secara intensif. Kedekatan tempat tinggal, mempermudah partisipan untuk melakukan interaksi secara intensif dengan tetangga.

Jarak sosial yang tercipta antara waria dengan tetangga yang berjauhan membuat prasangka menetap tanpa bergaul terlebih dahulu. Beberapa warga yang jauh menunjukkan penolakannya saat dihadapkan dengan para waria.

Partisipan juga mendapati warga bersikap apatis. Ahmadi (2007) mengatakan bahwa sikap timbul karena adanya stimulus. Sikap tidak akan terbentuk tanpa interaksi. Jarak tempat tinggal yang jauh meminimalkan kesempatan waria untuk berinteraksi dengan warga, sehingga warga cenderung memunculkan sikap tidak peduli kepada waria.

Di lain sisi, sikap apatis warga kepada waria merupakan representasi dari masyarakat kota. Menurut Ferdinand Tonnies (dalam Daldjoeni, 1997) masyarakat kota merupakan masyarakat kontrak, di mana ikatan yang personal dan hal tradisionil tidak lagi penting. Di kota, seseorang cukup mengenal sesamanya berdasarkan kepentingannya saja (Daldjoeni, 1997).

Salah satu cara untuk mencapai jarak sosial yang dekat adalah dengan melakukan interaksi secara intensif. Interaksi tersebut diwujudkan partisipan 
dalam berbagai bentuk. Hasil penelitian ini menemukan bahwa waria menjalin interaksi interpersonal yang cukup baik. Partisipan juga menjalin kerjasama, meskipun beberapa kesulitan masih didapati.

Hampir semua partisipan menjalin komunikasi interpersonal secara rutin kepada tetangga, seperti saling menyapa. Beberapa tetangga yang dikenal dekat sering kongko, berbincang-bincang, dan bersenda gurau dengan partisipan. Penelitian Almog (2011) menghasilkan bahwa siswa berkebutuhan khusus menggunakan humor untuk menjalin interaksi sosial dengan teman-temannya. Waria yang merupakan kaum minoritas, juga seringkali bersenda gurau dengan tetangga. Partisipan dapat menjadikan humor sebagai pintu untuk memulai interaksi dengan orang yang baru dan mencairkan suasana yang kaku. Keakraban partisipan dengan tetangga tersebut lagilagi hanya terbatas pada lingkungan tertentu di sekitar rumah kos waria.

Sifat positif atau sifat baik menjadi penunjang hubungan sosial yang baik pula. Salah satu sifat baik yang dimiliki beberapa partisipan adalah bersikap royal kepada tetangga. Partisipan beberapa kali memberikan atau membelikan tetangga sesuatu.

Faaizah (2013) mengatakan bahwa waria aktif mengambil peran di lingkungan sosialnya dengan berbuat baik dan saling tolong menolong. Sikap waria tersebut kemudian mendorong penerimaan warga.

Para partisipan penelitian ini bersama waria lainnya juga berpartisipasi dalam kegiatan bersama warga di Gang ' $X$ '. Salah satu kegiatan yang aktif diikuti oleh partisipan adalah perayaan HUT RI yang diadakan setiap tahun. Saat perayaan tersebut, waria menyumbangkan penampilan di atas panggung, misalnya menari atau bernyanyi. Mereka seringkali diminta untuk menjadi juri lomba tari dan fashion show, bahkan mengajarkan tari kepada anak-anak sekitar yang hendak tampil.
Permasalahan penerimaan sosial dapat diselesaikan oleh waria dengan melakukan usaha kerasnya dan menampilkan prestasi yang dapat menjanjikan di masa depan (Koeswinarno, 2004). Waria yang menampilkan bakat-bakatnya, menunjukkan bahwa mereka memiliki kesempatan untuk berhenti menjadi PSK dan beralih profesi yang lebih mulia.

Kegiatan bersama warga lainnya yang rutin diikuti oleh partisipan adalah arisan ibu-ibu. Hal ini menunjukkan adanya rasa percaya satu sama lain antara tetangga dengan partisipan. Penelitian yang dilakukan Saparudin (2015) menghasilkan bahwa waria di Tarakan Utara mengikuti berbagai kegiatan bersama warga, seperti berkumpul bersama ibu-ibu PKK, serta berpartisipasi dalam kegiatan bersama warga sekitar.

Beberapa partisipan juga sering mendapatkan undangan pesta warga seperti pernikahan ataupun khitanan. Waria diundang untuk menampilkan hiburan selain hanya sebagai tamu di acara tersebut. Jadi, pada acara pribadi warga pun waria dapat berpartisipasi.

Beberapa partisipan memiliki rasa dermawan untuk memberikan kontribusi materi demi kepentingan Gang ' $\mathrm{X}$ '. Misalnya dengan memberi sumbangan rutin untuk kerja bakti. Waria juga rutin membayar iuran warga, bahkan mereka tidak jarang memberikan berbagai macam sumbangan materi untuk kegiatan bersama.

Usaha menjalin interaksi yang dilakukan oleh partisipan tentu saja tidak luput dari kesulitan dan permasalahan. Ningsih \& Syafiq (2014) menemukan dampak seseorang menjadi waria adalah mengalami beberapa permasalahan baik psikologis maupun sosial. Secara sosial waria mendapatkan stigma dari masyarakat (public stigma) berupa hinaan dan penolakan. Menurut Pyror \& Reeder (2013) public stigma ditunjukkan melalui reaksi sosial dan psikologis masyarakat terhadap individu yang terstigma. 
Para partisipan melaporkan pengalaman mereka yang diperlakukan dengan buruk oleh pemuda-pemuda yang mabuk malam hari. Waria pernah mendapatkan teguran bahkan usiran dari tetangga. Beberapa partisipan juga sering digoda oleh pemuda yang lewat di depan rumah kos waria. Apabila orang menggoda terlalu berlebihan sampai menghina, partisipan akan merasa tersinggung dan tidak nyaman.

Warga dari gang lain terkadang melewati Gang ' $\mathrm{X}$ ' dan saat bertemu dengan waria, mereka menghina serta mentertawakannya. Sebagian besar partisipan juga sering mendapatkan hinaan dari anak-anak kecil di Gang ' $X$ '. Beberapa partisipan juga masih merasa dihindari oleh orang-orang tertentu.

Suci yang lebih jarang berhadapan dengan orang lain, dia merasa bahwa dia memiliki kesulitan untuk menyesuaikan diri, sehingga untuk memulai komunikasi dengan orang lain saja, bagi Suci adalah hal yang sulit.

Partisipan yang mengalami berbagai pengalaman interaksi pasti pernah mengalami perasaan tertentu. Ningsih \& Syafiq (2014) mengatakan bahwa waria mengalami berbagai dampak psikologis akibat perubahannya menjadi seorang waria, yaitu merasa malu, takut tidak diterima oleh lingkungannya, serta beberapa gejolak batin.

Partisipan penelitian ini mengalami perasaan takut dan khawatir akan penolakan warga. Suci juga mengaku bahwa dirinya malu atas kondisi dirinya yang waria. Dia merasa berbeda dengan orang pada umumnya, sehingga perbedaan tersebut membuatnya merasa tidak percaya diri apabila berhadapan dengan orang lain.

Perbedaan antara Suci dengan partisipan lain dapat dijelaskan oleh konsep harga diri waria yang diteliti oleh Pahlawani (2011). Suci berdasarkan ciriciri yang diungkap dalam penelitian tersebut merupakan waria yang memiliki harga diri rendah. Dia kurang aktif, kurang percaya diri, sulit dalam proses sosialisasi, serta pasif.

Partisipan perlu melakukan penyesuaian sosial untuk mendapatkan kenyamanan dalam menjalin hubungan sosial dengan orang-orang sekitar. Penyesuaian sosial bukan hal yang mudah bagi kaum minoritas seperi waria. Penyesuaian sosial adalah penjalinan hubungan secara harmonis dengan lingkungan sosial, mempelajari pola tingkah laku atau mengubah kebiasaan sedemikian rupa sehingga sesuai bagi masyarakat sosial (Chaplin, 2006). Para partisipan pun membentuk sikap diri yang sesuai dengan lingkungan untuk dapat menyesuaikan dirinya di Gang ' $X$ '.

Usaha yang dilakukan oleh partisipan untuk dapat melakukan penyesuaian sosial adalah dengan mendekatkan diri kepada tetangga. Seperti memulai pembicaraan dan senda gurau, serta berusaha berbuat baik dan menjadi yang berguna bagi warga Gang ' $X$ '. Penelitian yang dilakukan oleh Prabowo (2006) menghasilkan bahwa keterbukaan waria dalam berinteraksi sosial dan bergaul sepenuhnya diikuti oleh penerimaan masyarakat.

Beberapa hal yang dilakukan oleh para partisipan di atas tidak terlepas dari bantuan para waria lain yang telah lebih dahulu tinggal di Gang ' $X$ '. Mereka akan memperkenalkan waria baru dengan tetangga sekitar yang telah akrab.

Strategi lain yang dilakukan adalah dengan aktif dalam berbagai kegiatan kampung. Menampilkan diri dalam beberapa pertunjukkan dapat dijadikan waria sebagai salah satu penunjang hubungan sosialnya dengan warga sekitar. Terkait hal ini, penelitian Rachman (2014) menemukan bahwa waria menggunakan pertunjukkan sebagai politik identitas, sehingga banyak waria yang berhasil diterima dan lebih dekat dengan masyarakat sekitar.

Selain itu, Susanti (2014) menyebutkan bahwa dalam menegoisasikan penerimaan masyarakat mereka 
melakukan strategi penyesuaian dengan menunjukkan sisi positifnya pada masyarakat.

Tampak pula upaya para waria di Gang "X" untuk menjaga hubungan baik dengan Ketua RT melalui wakil senior mereka yang merupakan warga asli di sana, yaitu Sonya. Hal ini senada dengan penelitian Saparudin (2015) yang menyatakan bahwa salah satu usaha waria untuk menyesuaikan diri adalah dengan memperluas jaringan dengan pihak yang memiliki kuasa agar mendapatkan perlindungan dan penilaian baik dari orang lain. Adanya relasi yang cukup luas membuat waria mendapatkan pengakuan di tengah kehidupan sosialnya.

Terkait kesulitan partisipan dalam berinteraksi, mereka menemukan strategi coping untuk mengatasinya. Menurut Baron \& Byrne (2004) coping adalah respon seseorang saat dirinya menghadapi suatu situasi yang bermasalah. Respon tersebut berusaha untuk mengontrol, mentolerir serta mengurangi efek negatif dari situasi permasalahan yang dihadapi. Waria pada umumnya menanggapi hinaan dan cemoohan masyarakat dengan cara menahan emosi negatif, pasrah, tegar, dan memilih antara menjaga kontak sosial yang baik, atau menarik diri dari lingkungan (Herdyansyah, 2007; Ningsih \& Syafiq, 2014).

Beberapa cara yang dilakukan oleh partisipan selama ini bermacam-macam. Para partisipan lebih sering mengatur emosi saat menghadapi situasi yang mengecewakan atas perlakuan masyarakat khususnya warga atau menggunakan emotion focused coping (Lazarus, 1984). Di antaranya dengan bersabar, berserah diri, menginterospeksi diri, menahan emosi negatif, serta menerima. Partisipan menganggap perlakuan buruk wajar terjadi terhadap mereka yang memang memiliki kondisi yang berbeda. Mereka menerima stigma masyarakat kepada dirinya, atau bisa juga disebut stigma diri. Pyror \& Reeder (2013) mengatakan bahwa stigma diri terjadi ketika individu yang terstigma meyakini dan menyetujui bahwa dirinya memang sesuai dengan stigma yang diberikan oleh masyarakat.

Strategi coping yang paling sering ditemui adalah dengan menghindari permasalahan dan memandang positif suatu masalah, bahkan cenderung menganggapnya remeh atau sebagai lelucon (distancing) (Lazarus \& Folkman, 1984). Mereka bersikap masa bodoh saat mendapati orang menghina dirinya, bahkan mereka anggap hinaan atau sikap usil orang kepada mereka merupakan gurauan.

Strategi mengatur emosi, tidak sepenuhnya dapat berhasil dilakukan terus menerus oleh orang-orang tertentu. Icha mengekspresikan kemarahannya ketika dirasa perlakuan buruk orang lain terlalu berlebihan, dan ketika suasana hatinya sedang tidak baik. Dia dapat mengatakan secara langsung kepada orang yang memperlakukannya dengan buruk.

Mereka juga melakukan suatu tindakan untuk menyelesaikan permasalahannya. Usaha ini adalah salah satu dari bentuk problem focused coping, di mana individu aktif mencari penyelesaian dari masalah untuk mengatasi situasi penuh tekanan (Lazarus \& Folkman, 1984). Partisipan akan meminta maaf apabila terjadi sesuatu yang membuat tetangga merasa terganggu akan keberadaan mereka. Partisipan mencoba untuk mencegah warga merasa takut dan menghindari mereka. Mereka melaporkan mengenai kegiatan mereka yang sering memberikan sosialisasi atau penyuluhan bagi warga mengenai HIV/AIDS. Warga lebih memahami kondisi tersebut apabila diberi informasi secara langsung, karena pada umumnya penolakan warga diakibatkan oleh waria yang beresiko tinggi akan HIV/AIDS.

Anggapan mengenai diskriminasi yang biasa didapatkan oleh waria tidaklah berlebihan seperti sepuluh atau dua puluh tahun ke belakang. Berbagai usaha waria dan peran serta 'habituasi' membuat warga mulai menerima, atau sekedar tidak 
menolak keberadaan waria di lingkungannya. Waria di Indonesia memang belum pasti diterima oleh masyarakat, namun tidak lagi disudutkan atau diasingkan di sudut-sudut kota (Oetomo, 2001). Sejak lama waria telah memperjuangkan hakhaknya di Indonesia, sehingga diskriminasi terhadap waria secara perlahan-lahan luntur, dan tidak lagi terlihat terlalu ekstrim.

\section{Simpulan}

Penelitian ini bertujuan untuk mengetahui secara personal bagaimana pengalaman interaksi sosial serta penyesuaian sosial waria di Gang ' $\mathrm{X}$ ' Surabaya. Kedua tujuan tersebut terjawab melalui empat tema yaitu persepsi waria terhadap penerimaan warga, pengalaman berinteraksi secara langsung, penyesuaian sosial, serta strategi mengatasi masalah dan kesulitan berinteraksi.

Berdasarkan hasil penelitian dan pembahasan yang telah dijelaskan pada bagian sebelumnya, maka dapat disimpulkan bahwa partisipan memiliki persepsi yang beragam dalam memandang penerimaan warga. Mereka merasa diterima oleh sebagian warga, namun juga menyadari sebagian lain menolaknya. Namun sebagian besar warga justru cenderung bersikap apatis terhadap mereka.

Partisipan memiliki beragam pengalaman berinteraksi secara langsung dengan orang sekitar, baik interaksi yang bersifat antar individu atau kelompok, interaksi positif atau negatif, dan interaksi yang didasari beberapa tujuan. Pengalaman-pengalaman tersebut tentu tidak lepas dari permasalahan interaksi yang menimbulkan perasaan tertentu bagi partisipan.

Mereka menjadikan pengalaman mereka dalam berinteraksi sebagai salah satu cara untuk menyesuaikan diri secara sosial sehingga dapat diterima di lingkungan Gang ' $X$ '. Para partisipan juga melakukan berbagai cara untuk mengatasi masalah dan kesulitan berinteraksi dengan mengelolah emosi negatif maupun melakukan tindakan penyelesaian.

\section{Daftar Pustaka}

Ahmadi, A. (2007). Psikologi Sosial. Edisi Revisi. Jakarta: Rineka Cipta.

Almog, N. (2011). Academic and Social Adjustment of University Students with Visual Impairment. Tesis, tidak diterbitkan. Online. http://in.bgu.ac.il. Diakses 15 Juli 2015.

American Psychiatric Association. (2013). Diagnostic and Statistical Manual of Mental Disorders. Fifth Edition. Washington, DC.

Baron, R. A., \& Byrne, D. (2004). Psikologi Sosial. Edisi 10, Jilid 1. (Alih Bahasa: Ratna Djuwita). Jakarta: Penerbit Erlangga.
Braun, V., \& Clarke, V. (2006). Using Thematic Analysis in Psychology. Qualitative Research in Psychology, 3 (2), 77-101. Online. http://eprints.uwe.ac.uk. Diakses 29 Desember 2014.

Corrigan, P. W. (2004). Beat the Stigma and Discrimination! Four Lessons for Mental Health Advocates. Online. http://workingwelltogether.org.

Diakses 25 Januari 2015.

Daldjoeni, N. (1997). Seluk Beluk Masyarakat Kota. Bandung: Alumni.

Danandjaja, J. (2003). Diskriminasi Terhadap Minoritas Masih Merupakan Masalah Aktual di Indonesia sehingga Perlu 
Ditanggulangi Segera. Online. http://www.lfip.org. Diakses 15 Desember 2014.

Faaizah, L. (2013). Persepsi Masyarakat Muslim terhadap Waria dan Dampak Hubungan Sosial (Studi di Kampung Sidomulyo RT XVI RW XIV, Kelurahan Bener, Kecamatan Tegalrejo, Yogyakarta). Skripsi, tidak diterbitkan. Online. http://digilib.uinsuka.ac.id. Diakses 13 Juli 2015.

Haq, A. (2012). Ritual Bissu, Waria-Waria Sakti di Bone. Online. http://nasional.kompas.com. Diakses 15 Desember 2014.

Herdiansyah, H. (2011). Metodologi Penelitian Kualitatif: untuk IlmuIlmu Sosial. Jakarta: Salemba Humanika.

Hinshaw, S.P. (2005) The Stigmatisation of Mental Illness in Children and Parents: Developmental Issues, Family Concerns, and Researchneeds. Journal of Child Psychology and Psychiatry 46(7), 714-734.

Huang, K. (2012). Tales of the Waria: Inside Indonesia's Third-Gender Community. Online. http://huffingtonpost.com. Diakses 15 Desember 2014.

Kementerian Sosial Republik Indonesia. (2012). Kementerian Sosial dalam Angka, Pembangunan Kesejahteraan Sosial. Online. http://www.dissos.jabarprov.go.id. Diakses 9 Desember 2014.

Koeswinarno. (1993). Profil Waria Yogyakarta. Yogyakarta: PP Kependudukan Universitas Gajah Mada.

Koeswinarno. (2004). Hidup Sebagai Waria. Yogyakarta: LkiS.
Lazarus, R.S. \& Folkman, S. (1984). Stress, Apraisal, and Coping. New York: Springer.

Matsumoto, D. (2008). Pengantar Psikologi Lintas Budaya. (Alih Bahasa: Anindito Aditomo). Yogyakarta: Pustaka Pelajar.

Nadia, Z. (2005). Waria: Laknat atau Kodrat?. Yogyakarta: Pustaka Marwa.

Ningsih, E. S. W., \& Syafiq, M. (2014). Pengalaman Menjadi Pria Transgender (Waria): Sebuah Studi Fenomenologi. Character: Jurnal Penelitian Psikologi, 3, 1-6.

Oetomo, D. (2001). Memberi Suara pada yang Bisu. Yogyakarta: Galang Press.

Pahlawani, N. (2011). Dinamika Psikologis Harga Diri pada Waria. Skripsi, tidak diterbitkan. Online. http://eprints.ums.ac.id. Diakses 15 Juli 2015.

Prabowo, S. (2006). Studi Kasus Kehidupan Sosial Kaum Masyarakat Paiton Kabupaten Probolinggo. Online. http://studentresearch.umm.ac.id. Diakses 20 Juli 2015.

Pyror, J. B. \& Reeder, G. D. (2013). Stigma: Advances in Theory and Research. Basic and Applied Social Psychology. 35, 1-26. Online. http://portal.ou.nl. Diakses 30 Desember 2014.

Rachman, A. (2014). Waria Show: Politik Identitas Waria Pedesaan di Mojosari Mojokerto dan Nilai Edukasinya. Skripsi, tidak diterbitkan. Malang: Universitas Negeri Malang.

Saparudin. (2015). Strategi Waria Memperjuangkan Pengakuan Diri sebagai Jenis Kelamin Ketiga (Studi Kasus di Kelurahan Juata Laut, Kecamatan Tarakan Utara). eJournal 
Sosiatri - Sosiologi. 3 (3): 104-124. Online. http://ejournal.sos.fisipunmul.ac.id. Diakses 20 Juli 2015.

Soekanto, S. (2003). Sosiologi Suatu Pengantar. Jakarta: PT. Rajawali.

Suryadjaja, F. (2014). Kekerasan pada Kaum Transgender. Online. http://berita.suaramerdeka.com.

Diakses 12 Desember 2014.
Taylor, S. E., Peplau, L. A., \& Seas, D. O. (2009). Psikologi Sosial. Edisi Kedua Belas. (Alih Bahasa: Tri Wibowo B. S.). Jakarta: Kencana.

Winter, S. (2012). Lost in Transition: Transgender People, Rights, and HIV Vulnerability in The Asia-Pasific Region. Online. http://undp.org. Diakses 18 Desember 2014. 